\title{
Comparison of adsorption behaviour of coconut coir activated carbon and commercial activated carbon for textile dye
}

\author{
T. Khan \& M. Chaudhuri \\ Department of Civil Engineering, \\ Universiti Teknologi PETRONAS, Malaysia
}

\begin{abstract}
The objective of the study was to prepare activated carbon from coconut coir and compare its adsorption behaviour for textile dye with that of a commercial activated carbon. The coconut coir activated carbon (CCAC) and commercial activated carbon (CAC) were characterised in terms of ash content, bulk density, $\mathrm{pH}, \mathrm{pH}_{\mathrm{ZPC}}$, surface area, micropore area, micropore volume, average pore diameter, surface morphology and surface functional groups. Adsorption of a textile dye, Acid Red 18 (AR 18), by CCAC and CAC was examined. Batch adsorption test showed that extent of dye adsorption was dependent on dye concentration, contact time and $\mathrm{pH}$. Equilibrium adsorption was attained in 240 min and maximum adsorption occurred at $\mathrm{pH} 2$. Adsorption by CCAC and CAC followed pseudo-second-order kinetics and equilibrium adsorption data were described by the Freundlich and Langmuir isotherm models. CCAC showed higher adsorption capacity for the dye [25.7 (Freundlich) and 48.5 (Langmuir)] compared to that [12.0 (Freundlich) and 37.3 (Langmuir)] of CAC. CCAC is a suitable substitute for $\mathrm{CAC}$ in the removal of acid dyes from aqueous solution Keywords: Acid Red 18, activated carbon, adsorption, coconut coir, Freundlich isotherm, Langmuir isotherm.
\end{abstract}

\section{Introduction}

In order to colour their products, industries such as food, paper, carpet, rubber, cosmetic and plastic use dyes. Commercially, there are more than 100,000 available dyes with a world wide production of more than $7 \times 10^{5}$ metric tons per year. It is estimated that $10-15 \%$ of the dye is lost to waste streams during the 
dyeing process in the textile industry [1,2]. Due to synthetic origin and complex aromatic molecular structure, dyes are more stable and difficult to biodegrade [3]. Dyes can accumulate in sediment and soil at locations of wastewater discharge, and due to leaching from the soil groundwater systems are also affected [4]. Some dyes are mutagenic and carcinogenic and can cause severe damage to humans such as dysfunction of the kidney, reproductive system, liver, brain and central nervous system [5].

Dye waste treatment has been the target of concern not only because of the toxicity of the dyes but also due to their visibility [6]. Treatment methods such as chemical oxidation, ion exchange, evaporation, reverse osmosis and chemical precipitation have the disadvantages of high capital and operational cost and disposal of the residual sludge [7]. Adsorption by activated carbon is a promising technique for dye waste treatment. However, use of coal-based commercial activated carbon is limited because of its relatively high price and its feedstock is nonrenewable. Low-cost, renewable, and easily available plant-based materials need to be used as a source in the production of activated carbon.

In recent years, plant-based material such as silk cotton hull, coconut tree sawdust, banana pith, maize cob and sago waste [5] corncob wastes [8], coir pith [9], sawdust [10], rice husk [11], bagasse [12, 13], peach stone [14], seed shell [15] and sunflower seed hull [16] have been used as sources in the production of activated carbon for the treatment of textile dye waste. Coconut coir is an agricultural solid waste. In Malaysia, coconut is the fourth most important industrial crop in terms of total planted area. Coconut coir is available free of cost in large quantities from the coconut oil and desiccated product industry. Preparation of activated carbon from this agricultural solid waste would not only be economical but also solve part of solid waste disposal problem.

In this study, activated carbon was prepared from coconut coir and adsorption of a textile dye, Acid Red 18 (AR 18), from aqueous solution by the coconut coir activated carbon and a commercial activated carbon was examined.

\section{Materials and methods}

\subsection{Preparation of activated carbon}

Coconut coir activated carbon (CCAC) was prepared according to a method used by Santhy and Selvapathy [9] for preparing coir pith activated carbon. Washed and dried coconut coir was treated with concentrated sulphuric acid and kept in a hot-air oven at $105 \pm 5^{\circ} \mathrm{C}$ for $24 \mathrm{~h}$. Thereafter, the char was washed with water followed by washing with $2 \%$ sodium bicarbonate solution until effervescence had ceased and then kept in a $2 \%$ sodium bicarbonate solution overnight. The char was separated and washed with water until free from bicarbonate and dried at $105 \pm 5^{\circ} \mathrm{C}$ for $24 \mathrm{~h}$. It was then subjected to activation at $900^{\circ} \mathrm{C}$ for $30 \mathrm{~min}$ in an atmosphere of nitrogen. The activated carbon obtained was repeatedly washed with distilled water and soaked in $10 \%$ hydrochloric acid to remove calcium oxide, followed by repeated washing with water to remove free acid and drying 
at $105 \pm 5^{\circ} \mathrm{C}$ for $24 \mathrm{~h}$. The CCAC was ground to a size of $200-500 \mu \mathrm{m}$ and used in adsorption test.

A commercial activated carbon (CAC) was obtained from the Calgon Carbon Corporation, Pittsburgh, PA. It was ground to a size of 200-500 $\mu \mathrm{m}$ and used in adsorption tests.

\subsection{Textile dye}

A textile dye, Acid Red 18 (AR 18) was obtained in powdered form from Euro Chemo-Pharma Sdn. Bhd., Prai Industrial Estate, Penang, Malaysia.

\subsection{Adsorption test}

Batch adsorption test was carried out by shaking $100 \mathrm{~mL}$ of dye solution of desired concentration with $2 \mathrm{~g} / \mathrm{L}$ of activated carbon in a conical flask at room temperature $\left(22^{\circ} \mathrm{C}\right)$ using an orbital shaker at $150 \mathrm{rpm}$. After a predetermined contact time, the flask was removed from the orbital shaker and the supernatant was filtered through $0.45 \mu \mathrm{m}$ membrane filter, and the residual dye concentration was determined spectrophotometrically by measuring the absorbance at the wavelength of maximum absorbance $(508 \mathrm{~nm})$ against a standard curve. The effect of contact time (15-300 min), dye concentration $(40-100 \mathrm{mg} / \mathrm{L}), \mathrm{pH}(2-8)$ and carbon dosage $(1-8 \mathrm{~g} / \mathrm{L})$ on adsorption were determined. The adsorption isotherms for CCAC and CAC were determined by batch equilibrium test using the optimum contact time and $\mathrm{pH}$ for dye adsorption by the activated carbons.

\section{Results and discussion}

\subsection{Characterisation of activated carbon}

Various physical and chemical characteristics of CCAC and CAC are listed in table 1. CCAC possesses higher surface and micropore area, micropore volume and average pore diameter, and lower $\mathrm{pH}_{\mathrm{ZPC}}$ and $\mathrm{pH}$ than those of CAC.

Table 1: $\quad$ Physical and chemical characteristics of CCAC and CAC.

\begin{tabular}{|c|c|c|}
\hline Parameter & CCAC & CAC \\
\hline Surface area $\left(\mathrm{m}^{2} / \mathrm{g}\right)$ & 826 & 626 \\
\hline Micropore area $\left(\mathrm{m}^{2} / \mathrm{g}\right)$ & 551 & 509 \\
\hline Micropore volume $(\mathrm{mL} / \mathrm{g})$ & 0.25 & 0.23 \\
\hline Average pore diameter $(\AA)$ & 24 & 15.35 \\
\hline Ash content $(\%)$ & 14 & 22 \\
\hline Bulk density $(\mathrm{g} / \mathrm{mL})$ & 0.31 & 0.52 \\
\hline $\mathrm{pH}_{\mathrm{ZPC}}$ & 5.3 & 7.2 \\
\hline $\mathrm{pH}$ & 4.8 & 5.6 \\
\hline
\end{tabular}

\subsection{Scanning electron micrograph}

Scanning electron micrographs of CCAC and CAC at 200X magnification are shown in fig. 1. CCAC contains more macro- and micropores than the CAC. 


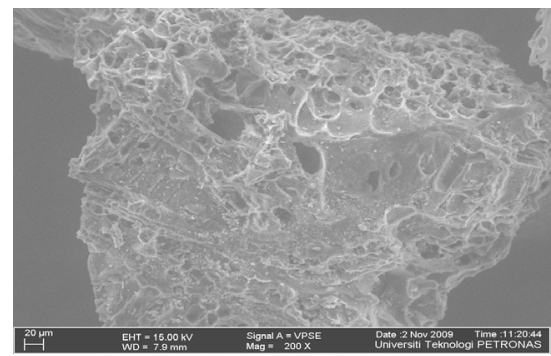

(A)

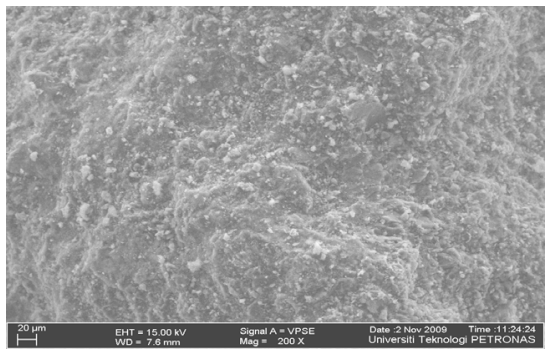

(B)

Figure 1: $\quad$ Scanning electron micrograph of (A) CCAC and (B) CAC.

\subsection{Fourier transform infrared (FTIR) spectroscopy}

The FTIR spectra recorded in the region of $500-4000 \mathrm{~cm}^{-1}$ for CCAC and CAC are shown in fig. 2 . The band at $3407 \mathrm{~cm}^{-1}$ corresponds to stretching vibration of $\mathrm{OH}^{-}$. Two weak bands at $2923-2852 \mathrm{~cm}^{-1}$ and at $2921-2850 \mathrm{~cm}^{-1}$ for CCAC and CAC, respectively indicate aliphatic group stretching vibration [17]. Large peaks observed at $2360 \mathrm{~cm}^{-1}$ and $2341 \mathrm{~cm}^{-1}$ for CCAC and CAC, respectively indicate antisymmetric stretching of $\mathrm{CO}_{2}[18]$. The peaks observed at approximately $1658 \mathrm{~cm}^{-1}$ and $1656 \mathrm{~cm}^{-1}$ for CCAC and CAC, respectively can be assigned to symmetric and asymmetric stretching vibration of $\mathrm{C}=\mathrm{C}$ group. The peaks at $1581 \mathrm{~cm}^{-1}$ and $1571 \mathrm{~cm}^{-1}$ for CCAC and CAC, respectively are due to aromatic rings of $\mathrm{C}=\mathrm{C}$. The intensity for $\mathrm{CCAC}$ was found to be greater than $\mathrm{CAC}$ at the peak $1402 \mathrm{~cm}^{-1}$, indicating the presence of pyrones and aromatic groups in CCAC. The small peaks in the region of $1100-1200 \mathrm{~cm}^{-1}$ for both

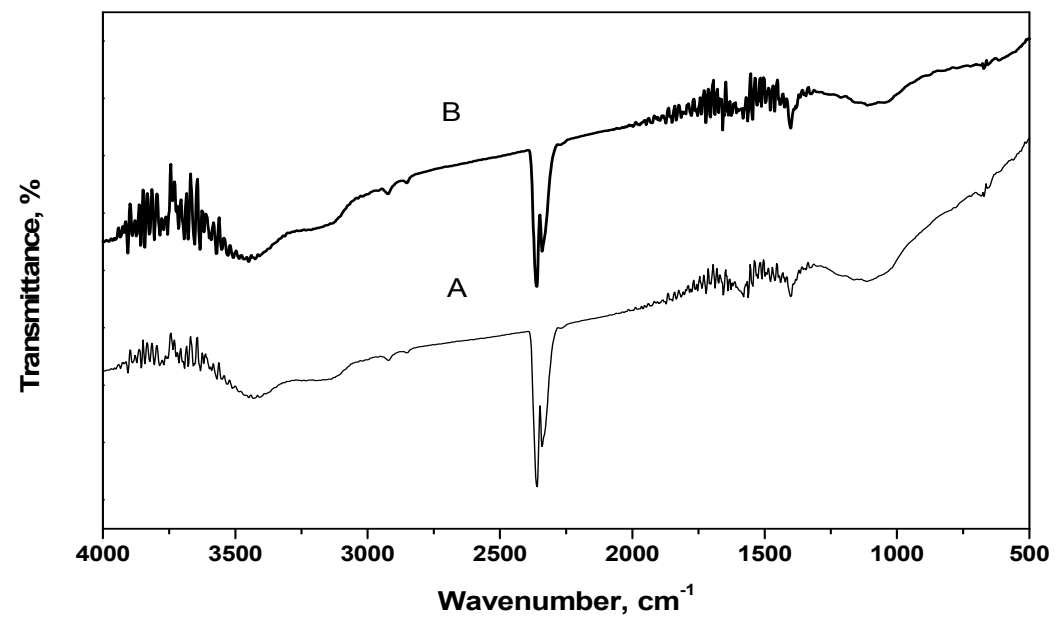

Figure 2: $\quad$ FTIR spectra of (A) CCAC and (B) CAC. 
CCAC and CAC can be assigned to the C-O stretching vibrations of carboxylic and phenolic groups [19]. The peaks in the region of $700-610 \mathrm{~cm}^{-1}$ are due to symmetric and asymmetric stretching of $\mathrm{SO}_{2}$ and symmetric stretching vibration of S-O groups, confirming the presence of surface $\mathrm{SO}_{2}$ complexes [17] in both CCAC and CAC.

\subsection{Adsorption test}

\subsubsection{Effect of contact time and dye concentration on adsorption}

The effect of contact time and dye concentration on adsorption of AR 18 by CCAC is shown in fig. 3. The extent of dye adsorption increased as the initial dye concentration decreased and as the contact time increased. Equilibrium adsorption was attained in $240 \mathrm{~min}$. Similar equilibrium contact time of $240 \mathrm{~min}$ also has been reported by Thinakaran et al. [15] for the adsorption of Acid Red 114 from aqueous solution using activated carbons prepared from seed shells.

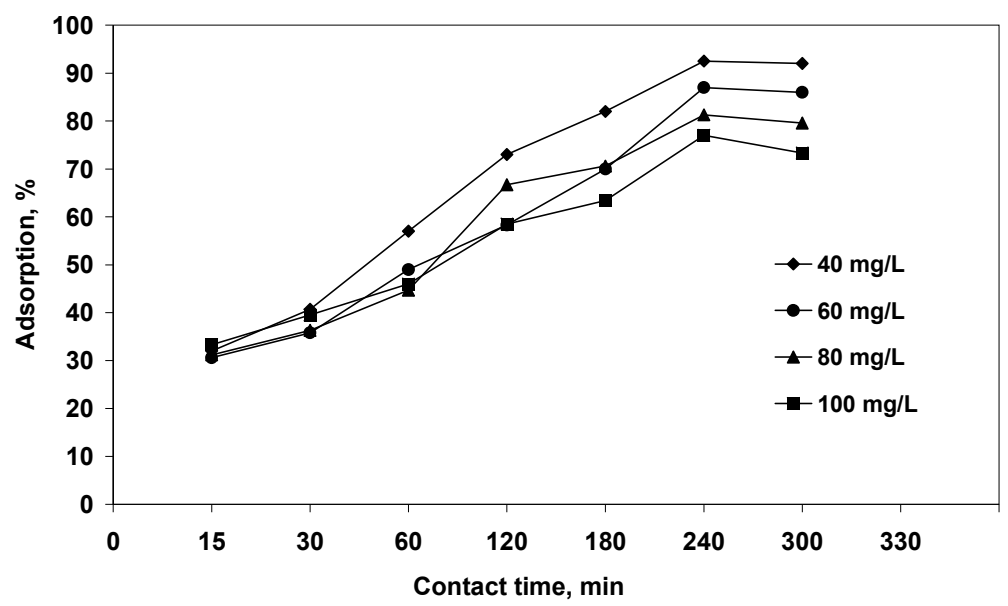

Figure 3: Effect of contact time and dye concentration on adsorption of AR 18 by CCAC.

\subsubsection{Effect of pH on dye adsorption}

The effect of $\mathrm{pH}$ on the adsorption of AR 18 by CCAC was studied by varying the $\mathrm{pH}$ of the dye solution in the range $2-8$, with $2 \mathrm{~g} / \mathrm{L}$ carbon dose and initial dye concentration of $80 \mathrm{mg} / \mathrm{L}$, fig. 4 . It is observed that maximum adsorption (91\%) occurred at acidic $\mathrm{pH} 2$. Similar observation has been reported by Thinakaran et al. [16] for adsorption of Acid Violet 17 by activated carbon prepared from sunflower seed hull. As the $\mathrm{pH}_{\mathrm{ZPC}}$ of $\mathrm{CCAC}$ is 5.3, the positive surface charge on the carbon surface increases in the acidic $\mathrm{pH}$ range and this would attract the negatively charged functional groups on the dye. $\mathrm{pH} 2$ was selected as optimum $\mathrm{pH}$ value for adsorption and all subsequent adsorption tests were conducted at $\mathrm{pH} 2$. 


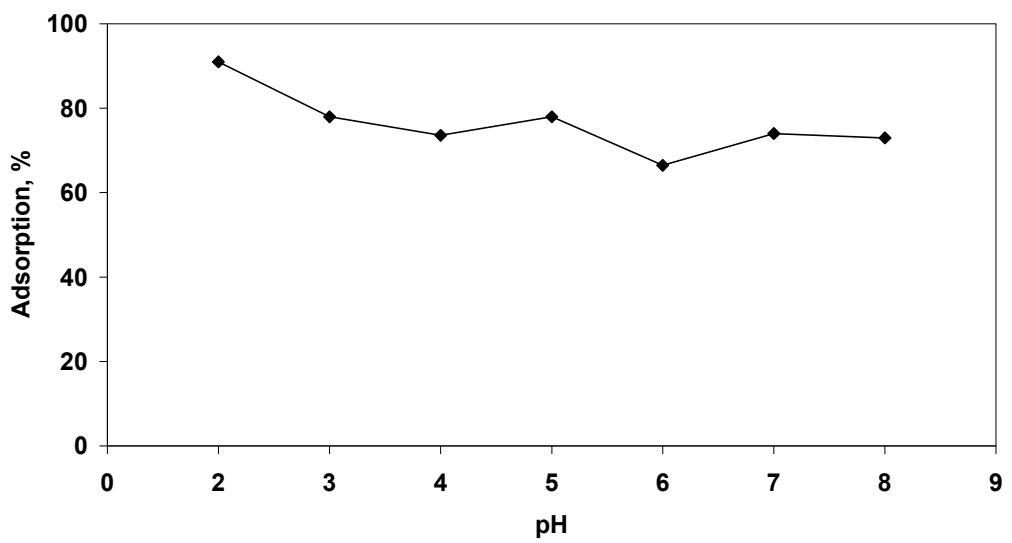

Figure 4: $\quad$ Effect of $\mathrm{pH}$ on adsorption of AR 18 by CCAC.

\subsubsection{Effect of carbon dose on dye adsorption}

Adsorption of AR 18 by CCAC from a $120 \mathrm{mg} / \mathrm{L}$ dye solution was studied by varying the carbon dose over a range of $1-8 \mathrm{~g} / \mathrm{L}$, employing a $\mathrm{pH}$ of 2 and a contact time of $240 \mathrm{~min}$. As shown in fig. 5, the maximum adsorption (99.5\%) occurred at $4 \mathrm{~g} / \mathrm{L}$ of carbon dose.

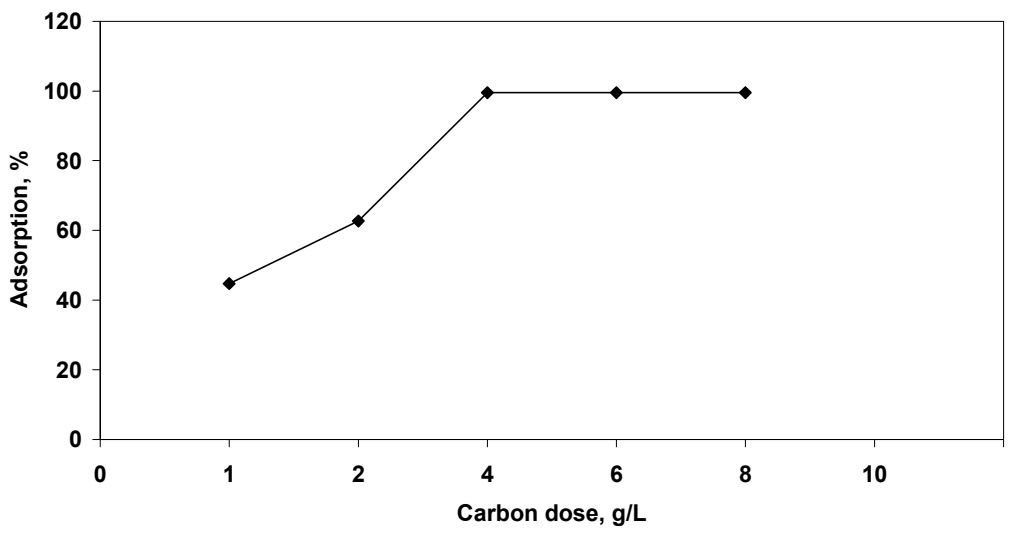

Figure 5: Effect of carbon dose on adsorption of AR 18 by CCAC.

\subsection{Adsorption isotherm}

In adsorption in a solid-liquid system, the distribution ratio of the solute between the liquid and the solid phase is a measure of the position of equilibrium. The preferred form of depicting this distribution is to express the quantity $q_{e}$ as a 
function of $C_{e}$ at a fixed temperature, the quantity $q_{e}$ being the amount of solute adsorbed per unit weight of the solid adsorbent, and $C_{e}$ the concentration of solute remaining in the solution at equilibrium. An expression of this type is termed an adsorption isotherm [20].

The Langmuir adsorption isotherm is

$$
q_{e}=\frac{Q^{o} b C_{e}}{1+b C_{e}}
$$

where, $Q^{\circ}$ is the amount of solute adsorbed per unit weight of adsorbent in forming a monolayer on the surface (monolayer adsorption capacity) and $b$ is a constant related to the energy of adsorption.

The Freundlich adsorption isotherm is

$$
q_{e}=K_{f} C_{e}^{1 / n}
$$

where, $K_{f}$ is the Freundlich constant (adsorption capacity) and $1 / n$ represents the adsorption intensity or surface heterogeneity.

Adsorption isotherms for AR 18 onto CCAC and CAC were determined by batch equilibrium test employing the optimum contact time $240 \mathrm{~min}$ and optimum pH 2 for both activated carbons. The isotherm data were fitted to the linear forms of the Langmuir equation, fig. 6 and the Freundlich equation, fig. 7, and values of the constants were determined, Table 2 . The values of $Q^{\circ}$ and $K_{f}$ indicate that CCAC exhibited higher adsorption capacity for AR 18 than CAC.

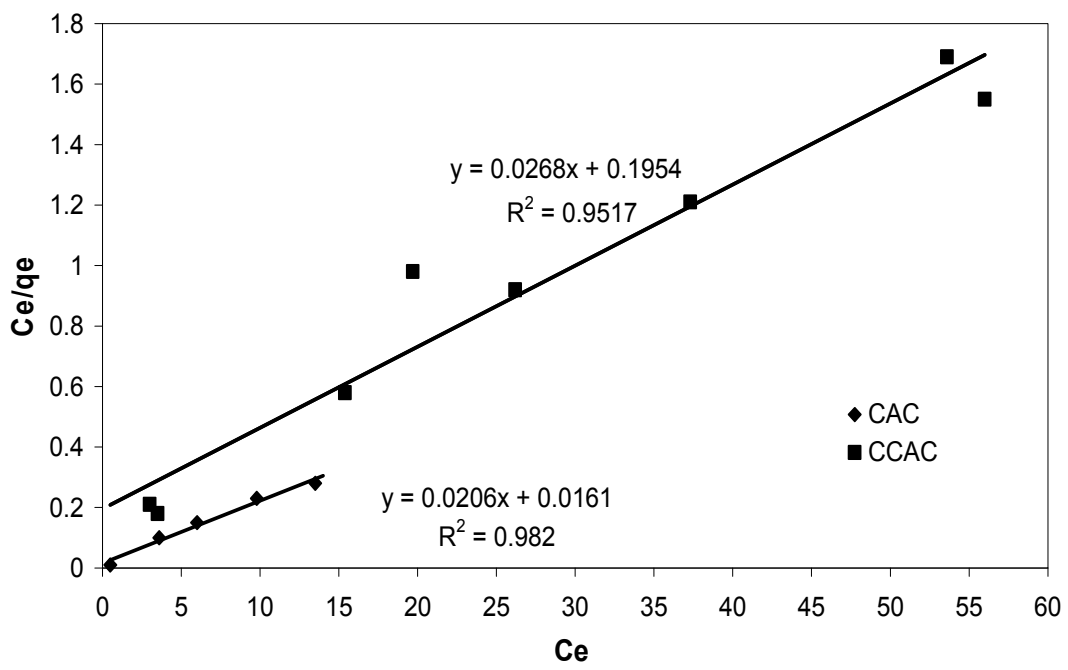

Figure 6: Langmuir adsorption isotherm of AR 18 adsorption. 
Table 2: Langmuir and Freundlich constants for AR 18 adsorption by CCAC and $\mathrm{CAC}$.

\begin{tabular}{|c|c|c|c|c|}
\hline \multirow{2}{*}{$\begin{array}{l}\text { Activated } \\
\text { carbon }\end{array}$} & \multicolumn{2}{|c|}{ Langmuir isotherm constant } & \multicolumn{2}{|c|}{ Freundlich isotherm constant } \\
\hline & $Q^{\circ}(\mathrm{mg} / \mathrm{g})$ & $b(\mathrm{~L} / \mathrm{g})$ & $\overline{K_{f}}$ & $1 / n$ \\
\hline $\mathrm{CCAC}$ & 48.5 & 1.27 & 25.7 & 0.2 \\
\hline $\mathrm{CAC}$ & 37.3 & 0.13 & 12.0 & 0.2 \\
\hline
\end{tabular}

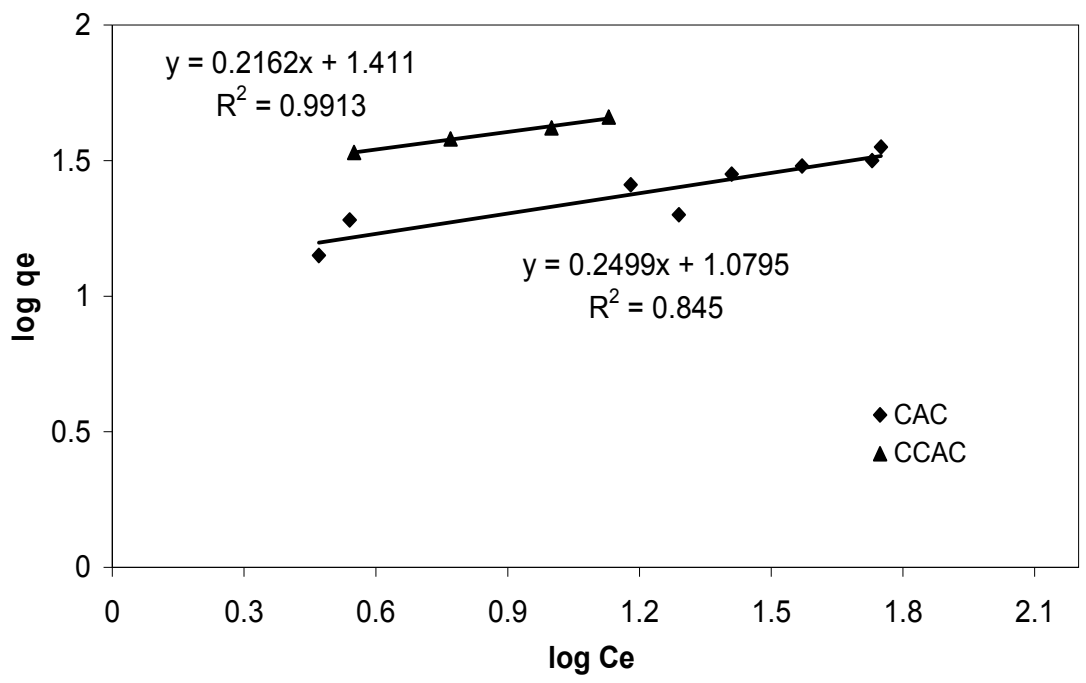

Figure 7: Freundlich adsorption isotherm of AR 18 adsorption.

\subsection{Adsorption kinetics}

A kinetic study for adsorption of AR 18 by CCAC and CAC was carried out by using two models i.e. the pseudo-first-order and pseudo-second-order.

The linear form of the pseudo-first-order model is

$$
\log \left(q_{e}-q_{t}\right)=\log q_{e}-\frac{k_{1} t}{2.303}
$$

The linear form of the pseudo-second-order model is

$$
\frac{t}{q_{t}}=\left(\frac{1}{k_{2} q_{e}^{2}}\right)+\left(\frac{t}{q_{e}}\right)
$$

where, $q_{e}$ and $q_{t}$ are the amounts of dye adsorbed $(\mathrm{mg} / \mathrm{g})$ at equilibrium and any time $t$, respectively; $k_{1}$ is the equilibrium rate constant of pseudo-first-order kinetics $\left(\mathrm{min}^{-1}\right)$; and $k_{2}$ is the equilibrium rate constant of pseudo-second-order kinetics $(\mathrm{g} / \mathrm{mg} \cdot \mathrm{min})$. 
Plots of $\log \left(q_{e}-q_{t}\right)$ versus $t$ and of $t / q_{t}$ versus $t$ are presented in fig. 8 and 9 , respectively, while table 3 lists the values of $k_{1}, k_{2}, q_{e}$ and $\mathrm{R}^{2}$ for the two models. Comparatively higher values of $\mathrm{R}^{2}$ for the pseudo-second-order kinetic model than those for the pseudo-first-order kinetic model, and the close values of $q_{e}$, calc and $q_{e}$, exp indicate that the pseudo-second-order kinetic model gave better fit to the experimental data for both activated carbons. Similar observations have been reported for the adsorption of Acid Violet 17 onto activated carbon prepared from sunflower seed hull [16] and acid dyes onto activated carbon cloth [21].

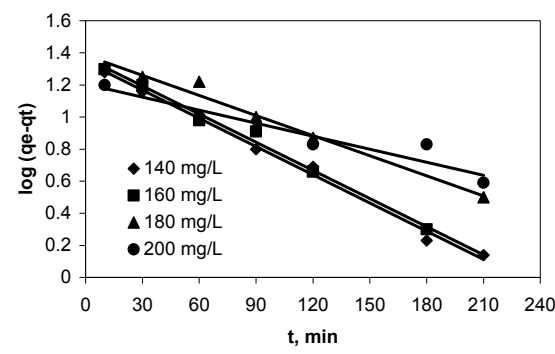

(A)

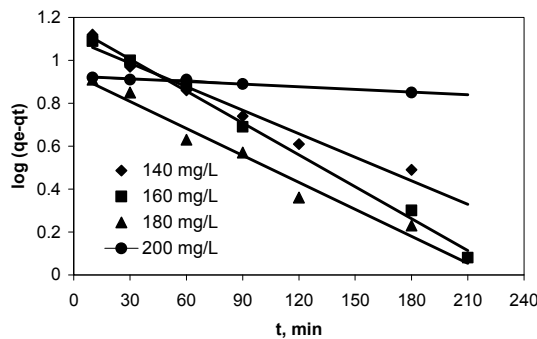

(B)

Figure 8: Pseudo-first-order kinetics of AR 18 adsorption by (A) CCAC and (B) CAC.

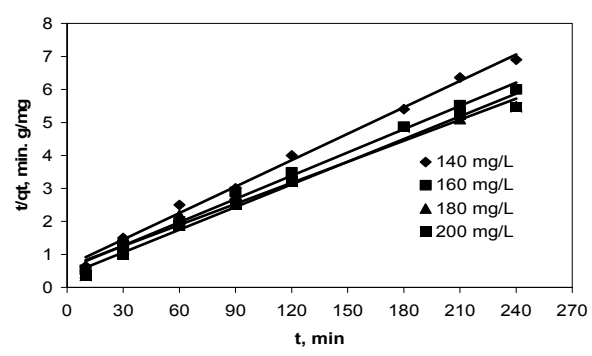

(A)

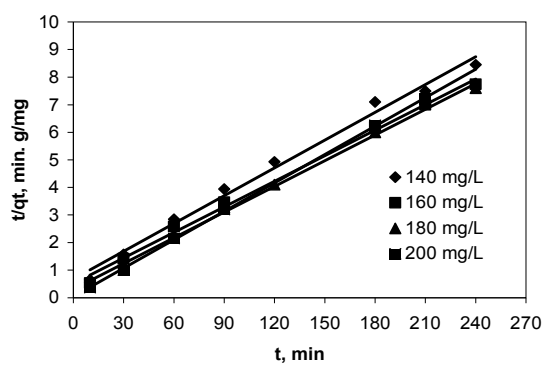

(B)

Figure 9: Pseudo-second-order kinetics of AR 18 adsorption by (A) CCAC and (B) CAC.

\section{Conclusions}

The adsorption capacity of coconut coir activated carbon for Acid Red 18 was higher than that of a commercial activated carbon, with the adsorption kinetics for both activated carbons following the pseudo-second-order model. Coconut coir activated carbon is a suitable substitute for commercial activated carbon in the adsorption of acid dyes from aqueous solution. 
Table 3: $\quad$ Pseudo-first-order and pseudo-second-order kinetic rate constants and experimental and calculated $q_{e}$ values of AR 18 adsorption by CCAC and CAC.

\begin{tabular}{|c|c|c|c|c|c|c|c|}
\hline $\begin{array}{c}\text { Activated } \\
\text { carbon } a_{n d} \\
\text { initial dye } \\
\text { concentration }\end{array}$ & $\begin{array}{l}q_{e}, \exp \\
(\mathrm{mg} / \mathrm{g})\end{array}$ & \multicolumn{3}{|c|}{$\begin{array}{l}\text { Pseudo-first order model } \\
k_{1} \times 10^{-3}\left(\mathrm{~min}^{-1}\right) \quad q_{e}, \mathrm{cal}(\mathrm{mg} / \mathrm{g}) \mathrm{R}^{2}\end{array}$} & \multicolumn{3}{|c|}{$\begin{array}{l}\text { Pseudo-second-order model } \\
k^{2} \times 10^{-3}(g / m g \text { min }) \quad q_{e} \text { cal }(\mathrm{mg} / \mathrm{g}) \quad \mathrm{R}^{2}\end{array}$} \\
\hline \multicolumn{8}{|l|}{ CCAC } \\
\hline $140 \mathrm{mg} / \mathrm{L}$ & 34.7 & 13 & 22.0 & 0.9939 & 1.1 & 37.4 & 0.9944 \\
\hline $160 \mathrm{mg} / \mathrm{L}$ & 38.9 & 13 & 23.4 & 0.9904 & 1.0 & 42.5 & 0.9936 \\
\hline $180 \mathrm{mg} / \mathrm{L}$ & 43.7 & 9.6 & 24.2 & 0.9793 & 0.7 & 46.9 & 0.9809 \\
\hline $200 \mathrm{mg} / \mathrm{L}$ & 43.9 & 6.2 & 16.0 & 0.9135 & 1.4 & 43.6 & 0.9853 \\
\hline \multicolumn{8}{|l|}{ CAC } \\
\hline $140 \mathrm{mg} / \mathrm{L}$ & 28.4 & 8.5 & 12.5 & 0.9635 & 1.7 & 29.7 & 0.9904 \\
\hline $160 \mathrm{mg} / \mathrm{L}$ & 31.0 & 11 & 14.2 & 0.9943 & 1.9 & 32.3 & 0.9957 \\
\hline $180 \mathrm{mg} / \mathrm{L}$ & 31.3 & 9.6 & 8.5 & 0.9644 & 3.2 & 32.1 & 0.9974 \\
\hline $200 \mathrm{mg} / \mathrm{L}$ & 36.0 & 9.2 & 9.2 & 0.9692 & 31.0 & 29.0 & 0.9996 \\
\hline
\end{tabular}

\section{Acknowledgements}

The authors are thankful to the management and authorities of the Universiti Teknologi PETRONAS (UTP) and the Civil Engineering Department, UTP for providing facilities for this research.

\section{References}

[1] Al-Ghouti, M.A., Khraisheh, M.A.M., Allen, S.J. \& Ahmed, M.N., The removal of dyes from textile wastewater: a study of the physical characteristics and adsorption mechanisms of diatomaceous earth. Journal of Environmental Management, 69 (3), pp. 229-238, 2003.

[2] Pearce, C.I., Lloyd, J.R. \& Guthrie, J.T., The removal of colour from textile wastewater using whole bacterial cells: a review. Dyes and Pigments, 58 (3), pp. 179-196, 2003.

[3] Eren, Z. \& Acar, F.N., Adsorption of Reactive Black 5 from an aqueous solution: Equilibrium and kinetic studies. Desalination, 194 (1-3), pp. 1-10, 2006.

[4] Namasivayam, C. \& Sumithra, S., Removal of Direct Red 12B and Methylene Blue from water by adsorption onto $\mathrm{Fe}(\mathrm{III}) / \mathrm{Cr}$ (III) hydroxide, an industrial solid waste. Journal of Environmental Management, 74 (3), pp. 207-215, 2005.

[5] Kardievelu, K., Kavipriya, M., Karthica, C., Radhika, M., Vennilamani, N. \& Pattabhi, S., Utilization of various agricultural wastes for activated carbon preparation and application for the removal of dyes and metal ions from aqueous solutions. Bioresource Technology, 87 (1), pp. 129-132, 2003.

[6] Aksu, Z. \& Tezer, S., Biosorption of reactive dyes on the green alga Chlorella vulgaris. Process Biochemistry, 40 (3-4), pp. 1347-1361, 2005. 
[7] Sharma, D.C. \& Forester, C.F., A preliminary examination into the adsorption of hexavalent chromium using low-cost adsorbents. Bioresource Technology, 47 (3), pp. 257-264, 1994.

[8] Wu, F.C., Tseng, R.L. \& Juang, R.S., Adsorption of dyes and phenols from water on the activated carbons prepared from corncob wastes. Environmental Technology, 22 (2), pp. 205-213, 2001.

[9] Santhy, K. \& Selvapathy, P., Removal of reactive dyes from wastewater by adsorption on coir pith activated carbon. Bioresource Technology, 97 (11), pp. 1329-1336, 2006.

[10] Garg, V.K., Amita, M., Kumar, R. \& Gupta, R., Basic dye (methylene blue) removal from simulated wastewater by adsorption using Indian rosewood sawdust: A timber industry waste. Dyes and Pigments, 63 (3), pp. 243-250, 2004.

[11] Guo, Y., Yang, S., Fu, W., Qi, J., Li, R., Wang, Z. \& Xu H., Adsorption of malachite green on micro- and mesoporous rice husk-based active carbon. Dyes and Pigments, 56 (3), pp. 219-229, 2003.

[12] Juang, R.S., Wu, F.C. \& Tseng, R.L., Characterization and use of activated carbons prepared from bagasse for liquid-phase adsorption. Colloids and Surfaces A, 201 (1-3), pp. 191-199, 2002.

[13] Valix, M., Cheung, W.H. \& McKay, G., Preparation of activated carbon using low temperature carbonisation and physical activation of high ash raw bagasse for acid dye adsorption, Chemosphere, 56 (5), pp. 493-501, 2004.

[14] Gercel, O., Ozcan, A., Ozcan, A.S. \& Gercel, H.F., Capacity of activated carbon derived from peach stones by $\mathrm{K}_{2} \mathrm{CO}_{3}$ in the removal of acid, reactive and direct dyes from aqueous solution. Journal of Environmental Engineering, 135 (5), pp. 333-340, 2009.

[15] Thinakaran, N., Panneerselvam, P., Baskaralingam, P., Elango D. \& Sivanesan, S., Equilibrium and kinetic studies on the removal of acid red 114 from aqueous solutions using activated carbons prepared from seed shells. Journal of Hazardous Materials, 158 (1), pp. 142-150, 2008.

[16] Thinakaran, N., Baskaralingam, P., Pulikesi, M., Panneerselvam, P. \& Sivanesan, S., Removal of Acid Violet 17 from aqueous solution by adsorption onto activated carbon prepared from sunflower seed hul. Journal of Hazardous Materials, 151 (2-3), pp. 316-322, 2008.

[17] Gercel, O., Ozcan, A., Ozcan, A.S. \& Gercel, H.F., Preparation of activated carbon from a renewable bio-plant of Euphorbia rigida by $\mathrm{H}_{2} \mathrm{SO}_{4}$ activation and its adsorption behavior in aqueous solutions. Applied Surface Science, 253 (11), pp. 4843-4852, 2007.

[18] Shu, W.M., Hira, S.O., Suzuki, T. \& Nishi M.F., Radiochemical reactions between tritium oxides and carbon monoxide. Fusion Engineering and Design, 70 (2), pp.123-129, 2004.

[19] Sricharoenchaikul, V., Pechyen, C., Aht-Ong, D. \& Atong, D., Preparation and characterization of activated carbon from the pyrolysis of physic nut (Jatropha curcas L.) waste. Energy and Fuels, 22 (1), pp. 31-37, 2008. 
116 Ravage of the Planet III

[20] Weber W.J., Jr., Adsorption (Chapter 5). Physicochemical Processes for Water Quality Control, ed. W.J. Weber, Jr., Wiley-Interscience: New York, pp. 199-259, 1972.

[21] Hoda, N., Bayram, E. \& Ayranci, E., Kinetic and equilibrium studies on the removal of acid dyes from aqueous solutions by adsorption onto activated carbon cloth. Journal of Hazardous Materials, 137 (1), pp. 344-351, 2006. 